\title{
THE BIOLOGY OF ASTERIAS RUBENS L.: GROWTH AND REPRODUCTION
}

\author{
By H. G. Vevers, M.A. \\ Zoologist at the Plymouth Laboratory
}

(Text-figs. I-5)

\begin{tabular}{|c|c|c|c|c|c|c|c|c|c|}
\hline \multicolumn{10}{|c|}{ CONTENTS } \\
\hline Introduction & & 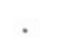 & & . & & & . & & I65 \\
\hline Distribution, & $\mathrm{Hab}$ & itat a & and Food & & . & . & . & & 165 \\
\hline Populations o & of $A s t$ & terias & $s$ rubens off & Plym & outh & & . & & 166 \\
\hline Growth Rate & & . & . & . & . & & . & & . \\
\hline Reproduction & & . & . & . & . & . & . & & I 76 \\
\hline Relation betw & veen & Ovar & rian Matur & ity anc & Bod & y Size & & & I8 $\mathrm{I}$ \\
\hline vary Length & hs an & a $\mathrm{Re}$ & lative Egg & Produ & action & & . & & I82 \\
\hline iscussion & . & . & . & . & . & . & . & & I 84 \\
\hline un & . & . & . & . & . & . & . & & I86 \\
\hline eferences & $0^{\circ}$ & . & . & . & . & . & 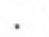 & & 186 \\
\hline
\end{tabular}

\section{INTRODUCTION}

The morphology and embryology of the common starfish, Asterias rubens L., have been extensively studied, but its general biology and, in particular, the details of its sexual maturity and spawning, have hitherto been largely neglected. This is the more surprising since the species is one of considerable negative economic importance, being a voracious consumer of marketable lamellibranchs and a competitor for food with many bottom-feeding fishes.

In the present work an attempt has been made to follow the cycle of gonad changes which occur throughout the year in populations of $A$. rubens occurring in the English Channel off Plymouth, and also to obtain data on its rate of growth, the relation between size and maturity and the factors influencing the onset of sexual maturity.

\section{Distribution, Habitat AND Food}

A. rubens is distributed throughout the north-east Atlantic from high water to a depth of $400 \mathrm{~m}$., sometimes to $650 \mathrm{~m}$. The geographical limits of its distribution are to the north, the White Sea and Iceland; to the east, the Baltic; and to the south, the coast of Senegal. It is not found off Greenland and only accidentally in the Mediterranean (Mortensen, 1927).

In his survey of the bottom fauna near the 30-fathom line from Eddystone to Start Point in south Devon, Allen (1899) found that it occurred on nearly all the grounds, varying from mud to coarse and shelly gravel and rock, 
although there were considerable differences in its abundance on the various substrata. He also observed that in this area its distribution was closely correlated with that of Chlamys opercularis (L.) which provides a large part of its food.

While still in a young stage it eats barnacles and small lamellibranchs. As an adult it feeds chiefly on worms, crustaceans, other echinoderms and many lamellibranchs, in particular C. opercularis and Mytilus edulis. In fact, it would appear to be omnivorous, eating any living or dead animal material on which it can get a firm hold.

\section{Populations of Asterias RUBENS OFF Plymouth}

As is usual with asteroids, size is expressed in the following study in terms of radius length, measured from the anus to the tip of the longest arm. The starfishes were all measured living, out of water, on a flat bench, so that each arm could be flattened out and straightened before measurement. Arm measurements (denoted as $R=$ radius length) were taken to the nearest millimetre, except those of starfishes with $R$ greater than $20 \mathrm{~cm}$., where arm contraction and expansion made the readings only accurate to the nearest $0.5 \mathrm{~cm}$.

Records were also kept of the length of the gonad in each measured arm. These measurements were taken from the central point of the blunt proximal end of the gonad to the tip of the most distal tubule. At the same time smears of each gonad measured were examined microscopically, and sections were cut of a number of gonads in each sample.

The difference in size composition of populations living under different conditions is clearly brought out by a comparison of the two main populations of $A$. rubens studied. The first population occurs on the Rame-Eddystone Grounds on a mixed substratum of sand and rough ground at a depth of 25-30 fathoms. The second population, which will be termed the Outer Grounds population, occurs some miles away to the south and south-west of Eddystone. The sea bottom in this area is largely composed of sand with patches of gravel, and it shelves gradually from a depth of $64 \mathrm{~m} .3$ miles south of Eddystone to $70 \mathrm{~m}$. at 6 miles south. The routine hauls for starfishes were all taken with an otter trawl.

\section{The Rame-Eddystone Grounds Population}

The means and ranges of the starfish samples taken in this area are shown in Table I. It will be seen that there are certain differences between one catch and another not always consistent with the period at which they were taken; for instance, the catch for 24 June 1947 has a lower size range and mean than that for I3 June 1947. This is to be expected in a species where growth is so directly dependent upon available food, and where it may cease altogether in places where the food supply is poor. It would not be possible with present 
bottom-sampling techniques to obtain periodic representative samples from any one small section of the main area, nor was such attempted.

Table I. Analysis of Hauls of Asterias RUBENS ON RAME-EDDYSTONE GROUNDS

\begin{tabular}{|c|c|c|c|c|c|c|c|c|}
\hline \multirow[b]{2}{*}{ Date } & \multirow{2}{*}{$\begin{array}{l}\text { Total } \\
\text { in } \\
\text { catch }\end{array}$} & \multicolumn{3}{|c|}{ Males } & \multicolumn{3}{|c|}{ Females } & \multirow{2}{*}{$\begin{array}{c}\text { Sex } \\
\text { not } \\
\text { known }\end{array}$} \\
\hline & & No. & Range & Mean $\sigma_{\mathrm{M}}$ & No. & Range & Mean $\sigma_{\mathrm{M}}$ & \\
\hline I. i.: 47 & 58 & 27 & $4 \cdot 0-15 \cdot 9$ & $9.24 \pm 0.56$ & 28 & $4.0-13.9$ & $9.43 \pm 0.48$ & 3 \\
\hline 4. ii. 47 & 30 & 15 & $4.0-12.9$ & $8.70 \pm 0.67$ & I2 & $4.0-14.9$ & $9 \cdot 75 \pm \mathrm{I} \cdot 06$ & 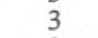 \\
\hline 27. iii. 47 & 44 & I6 & $3.0-13.9$ & $8.50 \pm 0.74$ & I9 & $3 \cdot 0-14.9$ & $8.66 \pm 0.63$ & 9 \\
\hline I6. iv. 47 & $4 \mathrm{I}$ & IO & $5.0-15.9$ & $8 \cdot 30 \pm I \cdot I I$ & I 8 & $5 \cdot 0-14.9$ & $9.33 \pm 0.6 I$ & I3 \\
\hline 28. iv. 47 & 87 & 34 & $3 \cdot 0-14 \cdot 9$ & $8.79 \pm 0.38$ & 42 & $5.0-13.9$ & $9.45 \pm 0.33$ & II \\
\hline I3. vi. 47 & 33 & I4 & $8.0-13.9$ & II. $15 \pm 0.32$ & I6 & $6.0-15.9$ & $\mathrm{II} \cdot \mathrm{I}_{3} \pm 0.68$ & 3 \\
\hline 24. vi.: 47 & 35 & II & $5 \cdot 0-14.9$ & $9.60 \pm 0.91$ & 23 & $7 \cdot 0-16 \cdot 9$ & II.02 \pm 0.52 & I \\
\hline 2. vii. 47 & 78 & 33 & $5 \cdot 0-22 \cdot 0$ & I $3.40 \pm 0.57$ & $3^{8}$ & $7 \cdot 0-17 \cdot 9$ & $12.66 \pm 0.42$ & 7 \\
\hline 3. vii. 47 & 50 & I 8 & $6 \cdot 0-2 I \cdot 0$ & II $.00 \pm 0.77$ & 22 & $7 \cdot 0-15 \cdot 9$ & II. $77 \pm 0.45$ & IO \\
\hline 24. vii. 47 & 42 & I5 & $3.0-16.9$ & $9.70 \pm 0.82$ & I9 & $5.0-15.9$ & $10.13 \pm 0.69$ & 8 \\
\hline 25. vii. 47 & 40 & I9 & $3.0-16.9$ & $9.66 \pm 0.84$ & I2 & $5.0-17.9$ & $9.83 \pm 0.96$ & 9 \\
\hline 7. viii. 47 & 68 & 30 & $7 \cdot 0-16 \cdot 9$ & II $27 \pm 0.39$ & 35 & $5.0-15.9$ & \pm 0.47 & 3 \\
\hline I9. viii. 47 & 78 & 27 & $3.0-16.9$ & $10.98 \pm 0.59$ & 44 & $6 \cdot 0-24 \cdot 0$ & $12.05 \pm 0.5 \mathrm{I}$ & 7 \\
\hline rr. ix. 47 & 77 & 28 & $3 \cdot 0-17 \cdot 9$ & $10.43 \pm 0.64$ & 45 & $3 \cdot 0-14 \cdot 9$ & $9.66 \pm 0.42$ & 4 \\
\hline 28. x. 47 & 38 & I2 & $6.0-15.9$ & II. $32 \pm 0.82$ & 18 & $8.0-15.9$ & II $\cdot 28 \pm 0.45$ & 8 \\
\hline I7. xi. 47 & 38 & I9 & $5 \cdot 0-18 \cdot 9$ & II $.08 \pm 0.8 I$ & I8 & $5 \cdot 0-16 \cdot 9$ & $10.56 \pm 0.79$ & I \\
\hline I6. i. 48 & 49 & 23 & $4.0-14.9$ & $9.98 \pm 0.6 \mathrm{I}$ & 26 & $4.0-15.9$ & $10.35 \pm 0.61$ & 0 \\
\hline Io. ii. 48 & $4 I$ & $2 \mathrm{I}$ & $4 \cdot 0-15 \cdot 9$ & $9.74 \pm 0.64$ & I3 & $4.0-13.9$ & $8.35 \pm 0.79$ & 7 \\
\hline $23 / 24$. iii. 48 & $6 \mathrm{I}$ & 23 & $4.0-15.9$ & $10.14 \pm 0.70$ & 32 & $4 \cdot 0-18 \cdot 9$ & $10.47 \pm 0.54$ & 6 \\
\hline II. v: 48 & 68 & 28 & $4.0-18.9$ & II $46 \pm 0.57$ & 38 & $5 \cdot 0-17 \cdot 9$ & $10.50 \pm 0.50$ & 2 \\
\hline 7. vi. 48 & 50 & 25 & $6.0-17.9$ & I0. $78 \pm 0.53$ & 25 & $6.0-17.9$ & II. $30 \pm 0.55$ & 0 \\
\hline \multirow[t]{2}{*}{ 2I. vi. 48} & I IO & 58 & $5 \cdot 0-16 \cdot 9$ & II. $57 \pm 0.36$ & 52 & $5 \cdot 0-19 \cdot 9$ & II I I $3 \pm 0.40$ & o \\
\hline & 1216 & 506 & & & 595 & & & II 5 \\
\hline
\end{tabular}

Table II. Analysis of Hauls of Asterias RubENS on Outer Grounds

\begin{tabular}{|c|c|c|c|c|c|c|c|c|}
\hline \multirow[b]{2}{*}{ Date } & \multirow{2}{*}{$\begin{array}{c}\text { Total } \\
\text { in } \\
\text { catch }\end{array}$} & \multicolumn{3}{|c|}{ Males } & \multicolumn{3}{|c|}{ Females } & \multirow{2}{*}{$\begin{array}{c}\text { Sex } \\
\text { not } \\
\text { known }\end{array}$} \\
\hline & & No. & Range & Mean $\sigma_{\mathrm{M}}$ & No. & Range & Mean $\sigma_{\mathrm{M}}$ & \\
\hline 20. iii. 47 & 33 & $\mathrm{I} 2$ & $6.0-16.9$ & $I 2.50 \pm 0.90$ & $2 I$ & $9 \cdot 0-2 I \cdot 9$ & $I 4.60 \pm 0.6 r$ & 0 \\
\hline 9. iv. 47 & 29 & II & $8 \cdot 0-18.9$ & $\mathrm{I} 2.68 \pm \mathrm{I} \cdot 02$ & I3 & $7.0-19.9$ & $13.27 \pm 0.85$ & 5 \\
\hline I8. iv. 47 & 50 & 25 & II.O-I9.9 & I $4.86 \pm 0.43$ & 25 & $9 \cdot 0-2 \mathrm{I} \cdot 9$ & $15.66 \pm 0.52$ & 0 \\
\hline 25. iv. 47 & I 75 & 66 & $5 \cdot 0-18 \cdot 9$ & $\mathrm{I} 4.2 \mathrm{I} \pm 0.32$ & 105 & $6 \cdot 0-18 \cdot 9$ & I $5.05 \pm 0.21$ & 4 \\
\hline $23 \cdot v \cdot 47$ & 57 & I7 & $9.0-15.9$ & I2.26 \pm 0.47 & 39 & $8 \cdot 0-16.9$ & $12.35 \pm 0.33$ & I \\
\hline I6. vi. 47 & IOI & 44 & $10.0-22.9$ & I5. $84 \pm 0.43$ & 57 & II. $0-23 \cdot 9$ & $16.45 \pm 0.33$ & 0 \\
\hline 4. vii. 47 & 213 & 83 & $8 \cdot 0-19 \cdot 9$ & I $4.79 \pm 0.27$ & 127 & $8 \cdot 0-2 I \cdot 9$ & I5. $49 \pm 0.25$ & 3 \\
\hline I6. vii. 47 & 172 & 89 & $7 \cdot 0-2 I \cdot 9$ & $16.56 \pm 0.28$ & 79 & $8 \cdot 0-22 \cdot 9$ & $16.92 \pm 0.36$ & 4 \\
\hline 27. viii. 47 & I 5 I & 63 & $9.0-19.9$ & $I 4.29 \pm 0.30$ & 85 & $8 \cdot 0-22 \cdot 9$ & $\mathrm{I} 4.88 \pm 0.28$ & 3 \\
\hline 2I.x. 47 & $7 \mathrm{I}$ & 36 & $6 \cdot 0-22 \cdot 9$ & $\mathrm{I} 4.72 \pm 0.5 \mathrm{I}$ & 34 & $I 0 \cdot 0-2 I \cdot 9$ & I5. $88 \pm 0.48$ & I \\
\hline I3. xi. 47 & 39 & I9 & $13.0-26.9$ & $18.55 \pm 0.93$ & 20 & $12.0-33.9$ & $17.95 \pm I .02$ & 0 \\
\hline I5. i. 48 & 29 & I5 & $5 \cdot 0-22 \cdot 0$ & I4.03 $\pm I \cdot I 9$ & I4 & $10 \cdot 0-2 \mathrm{I} \cdot 8$ & $15.36 \pm 0.95$ & 0 \\
\hline 4. ii. 48 & 15 & 7 & $9 \cdot 0-2 I \cdot 5$ & I3.64 \pm 1.53 & 8 & $7 \cdot \mathrm{I}-\mathrm{I} 6 \cdot \mathrm{I}$ & $12.0 \pm I .03$ & o \\
\hline I2. iii. 48 & 38 & I5 & $5 \cdot 9-16 \cdot 6$ & I $2.23 \pm 0.76$ & 20 & $8.9-I 8.8$ & $\mathrm{I} 4.35 \pm 0.6 \mathrm{I}$ & 3 \\
\hline I4. iv. 48 & $\mathrm{IO}_{3}$ & 50 & $8.0-20.0$ & $I 4.34 \pm 0.38$ & 53 & $7 \cdot 6-20 \cdot 5$ & I5. $88 \pm 0.43$ & 0 \\
\hline I3. v: $4^{8}$ & $23 I$ & 87 & $10.5-23.8$ & $16.89 \pm 0.32$ & 144 & $8 \cdot 8-25 \cdot 5$ & I $8.5 \mathrm{I} \pm 0.25$ & o \\
\hline I I. vi. 48 & I 48 & 64 & $7 \cdot 5-17 \cdot 8$ & I $3.48 \pm 0.32$ & 84 & $6 \cdot 2-23 \cdot 5$ & I $3.44 \pm 0.32$ & 0 \\
\hline 6. vii. 48 & 90 & 38 & $8 \cdot 4-2 I \cdot 5$ & $14.24 \pm 0.52$ & 52 & $7 \cdot 6-2 I \cdot 5$ & I $4.98 \pm 0.42$ & 0 \\
\hline \multirow[t]{2}{*}{ II. viii. 48} & 50 & 20 & $\mathrm{II} \cdot \mathrm{I}-22 \cdot 2$ & $15.00 \pm 0.66$ & 30 & $9 \cdot 6-27 \cdot 5$ & $15.6 \pm 0.73$ & o \\
\hline & I795 & $76 \mathrm{I}$ & & & roro & & & 24 \\
\hline
\end{tabular}




\section{The Outer Grounds Population}

The means and ranges of the starfish samples taken in this area are shown in Table II. This shows clearly the overall larger sizes of the starfishes in this area, compared with those in the Rame-Eddystone Grounds.

\section{The Population near E I}

A smaller number of samples was taken by trawling in the grounds near International Station E I (Io miles S.W. of Eddystone). The means and sizes of these samples are shown in Table III. The starfishes taken in this area are still larger than those on the Outer Grounds.

TABLE III. Analỵsis of HaUls of Asterias RUBENS NeAR E I

\begin{tabular}{|c|c|c|c|c|c|c|c|}
\hline \multirow[b]{2}{*}{ Date } & \multirow{2}{*}{$\begin{array}{l}\text { Total } \\
\text { in } \\
\text { catch }\end{array}$} & \multicolumn{3}{|c|}{ Males } & \multicolumn{3}{|c|}{ Females } \\
\hline & & No. & Range & Mean $\sigma_{\mathrm{M}}$ & No. & Range & Mean $\sigma_{M}$ \\
\hline 3. vi. 47 & I68 & 44 & II. $0-23.9$ & $17.98 \pm 0.42$ & I 24 & II $\cdot 0-30 \cdot 9$ & $20.36 \pm 0.31$ \\
\hline Io. vi. 47 & I9 & 7 & $16 \cdot 0-20 \cdot 9$ & $18.64 \pm 0.49$ & $\mathrm{I} 2$ & $18.0-23.9$ & $20.75 \pm 0.40$ \\
\hline I7. vi. 47 & 39 & 9 & $14.0-2 \mathrm{r} \cdot 9$ & $19.38 \pm 0.77$ & 30 & $15.0-27.9$ & $21.37 \pm 0.57$ \\
\hline I5. ix. 47 & 50 & $2 \mathrm{I}$ & I $4 \cdot 0-27 \cdot 9$ & $20.16 \pm 0.72$ & 29 & $15.0-28.9$ & $2 \mathrm{I} \cdot 43 \pm 0.69$ \\
\hline & 276 & $8 \mathrm{I}$ & & & I95 & & \\
\hline
\end{tabular}

\section{The Cawsand Bay Population}

A single haul was obtained from this area on 23 May 1947, and it consisted of I8 small starfishes. The means and range of the starfishes in this haul were:

$\begin{array}{lccc} & \text { No. } & \text { Range } & \text { Mean }(\mathrm{cm} .) \\ \text { Males } & 8 & 3 \cdot 0-4 \cdot 0 & 3 \cdot 7 \\ \text { Females } & \text { 10 } & 3 \cdot 0-8 \cdot 4 & 4 \cdot 3\end{array}$

\section{The Plymouth Sound Population}

In spring 1948 a new and very large population of $A$. rubens was found on Asia Grounds in Plymouth Sound, 800 m. W.S.W. of the Plymouth Laboratory. A small sample was obtained on Io February I 948 and a larger one on I6 April I948, both of which were examined for size and gonad maturity. The means and size ranges of these samples are shown in Table IV.

Table IV. Analysis of Hauls of Asterias Rubens on Asia Grounds in Plymouth Sound

\begin{tabular}{|c|c|c|c|c|c|c|c|}
\hline \multirow[b]{2}{*}{ Date } & \multirow{2}{*}{$\begin{array}{l}\text { Total } \\
\text { in } \\
\text { catch }\end{array}$} & \multicolumn{3}{|c|}{ Males } & \multicolumn{3}{|c|}{ Females } \\
\hline & & No. & Range & Mean $\sigma_{M}$ & No. & Range & Mean \\
\hline Io. ii. 48 & 25 & II & $8 \cdot 3-1 \mathrm{Ir} \cdot 0$ & $9.50 \pm 0.08$ & I4 & 6.6-IO.I & $8 \cdot 79 \pm 0.28$ \\
\hline iv. 48 & 100 & 52 & $5 \cdot 9-18 \cdot 4$ & $9 \cdot 30 \pm 0.28$ & 48 & $6 \cdot 0-\mathrm{II} \cdot 8$ & $9.54 \pm 0.21$ \\
\hline & I25 & 63 & & & 62 & & \\
\hline
\end{tabular}

In addition to these samples, hauls were also made on 3 and 4 March I948. On 3 March three $40-\mathrm{min}$. trawl hauls were made and the total catch was 
595 A. rubens. On 4 March four 40-min. trawl hauls yielded a total catch of 1259 A. rubens.

This population was undoubtedly the most homogeneous of those examined, and it was found to be feeding entirely on very rich beds of mussels (Mytilus edulis). In contrast with the starfishes caught outside Plymouth Sound, which were red-brown or more rarely pale yellowish brown in colour, the starfishes from Asia Grounds were, without exception, a bright red colour. In addition, there was a marked difference in body shape. Starfishes from the RameEddystone and Outer Grounds had thin, gradually tapering arms, whereas the Asia Grounds population had thick robust arms which tapered only in the distal part. These very distinct differences may be correlated with the differences in food supply of the starfishes from the two areas.

\section{The Rame Mud Population}

A single haul was taken with an Agassiz trawl on the Rame mud, 2 miles W.S.W. of Rame Head in 26 fathoms. Although the catch with this trawl is not strictly comparable with those taken with the otter trawl, it is interesting to note that no medium or large starfishes were taken, although these sizes have often been taken with an Agassiz trawl working on the Outer Grounds. The starfishes taken on the mud were all small or very small, with thin arms, coloured dark red-brown. The mean and range for the starfishes in this haul were:

$$
\begin{array}{cccc}
\text { Date } & \text { Total in catch } & \text { Range (cm.) } & \text { Mean }(\mathrm{cm} .) \\
\text { 7. iv. } 48 & 95 & \mathrm{I} \cdot 0-6 \cdot 4 & 2.52
\end{array}
$$

The above data are for both sexes, as the specimens in this catch were mostly too small and underdeveloped to allow the sex to be determined accurately.

\section{Comparison of the Size Compositions of the Populations}

The means and ranges have been used only to characterize the starfish populations of the different grounds, and it will be seen from Fig. I that the differences are marked. This graphical representation of the samples shows that, apart from the marked difference between the means, there was in the Outer Grounds a complete lack of the size classes $R_{3}-5 \mathrm{~cm}$. and a scarcity of the size classes $7-10 \mathrm{~cm}$; and this in spite of the large number of individuals taken in many of the Outer Grounds hauls. These size classes are all present in reasonable numbers in the Rame-Eddystone samples. This difference between the two sets of samples cannot be due to selective fishing by the trawl. It is unlikely that the same fishing gear used over similar substrata would select large and medium starfishes in the Outer Grounds and small and medium ones on the Rame-Eddystone Grounds if all three size groups were present in each area. It is considered that the trawl brings up from each ground a random sample of all those sizes which are present, with the exception of the smallest sizes ( $R$ under $3 \mathrm{~cm}$.). These smaller sizes were, in fact, present on 
the Rame-Eddystone Grounds in the spring and summer of the year, when they were caught in a few dredge hauls. They were not found on the Outer Grounds until about October, when a few small $\left(R \mathrm{ca} .3^{-6} \mathrm{~cm}\right.$.) starfishes were taken.

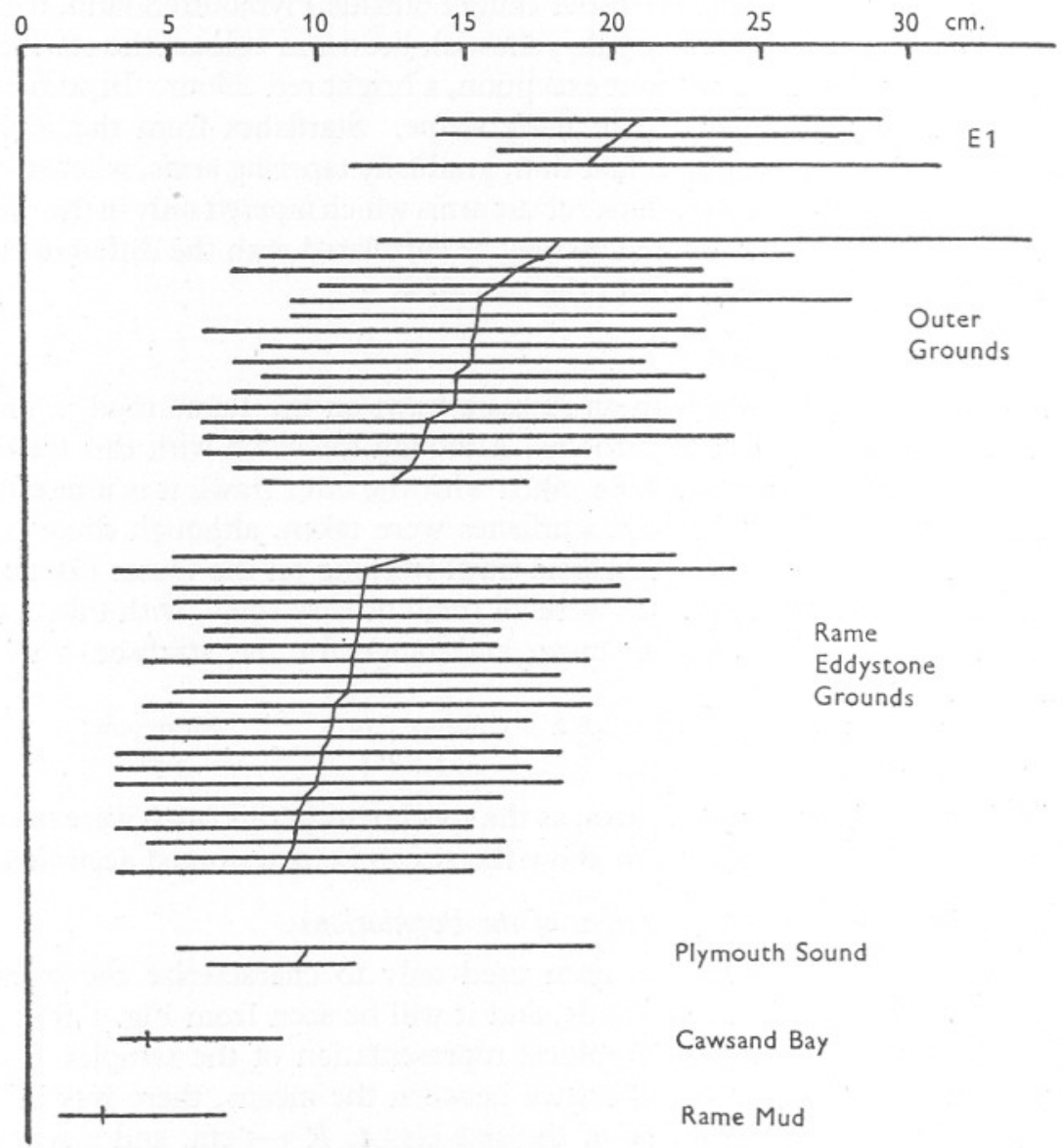

Fig. I. Size ranges and means (in $\mathrm{cm}$.) of six starfish populations off Plymouth. (Means joined by vertical lines.)

There are two possible explanations for the absence from the Outer Grounds of the small $\left(R_{3}-6 \mathrm{~cm}\right.$.) sizes. First, the 1946 starfish spat might have failed to settle in the Outer Grounds. This is very unlikely in view of the large breeding population on these grounds. But secondly, a proportion of the 1946 brood may have settled successfully in the Outer Grounds and prospered so well on the rich food there that by March-April 1947 they had already reached and passed the $6 \mathrm{~cm}$. size class. This would mean that by April 1947 there would be few, if any, starfishes with a radius length of less than $6 \mathrm{~cm}$. 
remaining on the Outer Grounds, and the chances of catching them in trawl or dredge would be slight. On this view it would be necessary to postulate a radial growth of a least $6 \mathrm{~cm}$. (and probably more) in the 9 months between metamorphosis in July 1946 and April I947; that is, an average monthly increment of rather less than one centimetre. That this is quite possible is shown by the laboratory observations on rate of growth in Asterias rubens recorded below.

The Plymouth Sound starfishes caught in 1948 could not have been younger than the 1947 brood, and they show means of $R=9.4 \mathrm{~cm}$. for the males and $R=9 \cdot 2 \mathrm{~cm}$. for the females. This very homogeneous population was almost certainly made up of one year-group only, and, again on the basis of laboratory observations, it is considered that they did, in fact, belong to the I947 brood. A large concentrated starfish population such as this, feeding on an abundant fixed food supply, will tend to remain localized in space and its individuals will be likely to grow at approximately similar growth rates so long as the food lasts. When the food is depleted the population will disperse and the growth rate of the individual starfishes will then become variable, leading to a population which is heterogeneous in size composition.

In contrast, the Rame Mud population with a mean $R=2.5$ must also have been at least IO or II months old, and probably represented the remains of one or more spatfalls which had fallen on a bottom poor in available starfish food.

\section{GRowth RATE}

During 1947 a number of starfishes taken on the Rame-Eddystone Grounds or from weed collected in Plymouth Sound were kept in laboratory tanks with an excess supply of graded sizes of Mytilus edulis, Tellina crassa and Chlamys opercularis. After about a week the starfishes became acclimatized to aquarium conditions and started feeding voraciously. Measurements of radius length were taken at intervals, and results are shown in Table V. (No attempt was made in these preliminary experiments to record the quantity of food consumed by each individual starfish, although further work on this subject is now in progress.) The data in Table $\mathrm{V}$ are shown graphically in the form of growth curves in Fig. 2. Growth is fastest during the summer, when the monthly increment may exceed $\mathrm{I} \mathrm{cm}$. Even during the winter growth continues, although at a reduced rate, and a further increase in rate occurs in spring.

Most of these observations were made on starfishes which were caught inshore in summer 1947 at sizes between 4 and $8 \mathrm{~cm}$. radius. Assuming that these belonged to the 1946 brood, they must have been growing at an average rate of $0.5 \mathrm{~cm}$. per month since metamorphosis II or I 2 months before. When fed with unrestricted supplies they grew at a somewhat faster rate. Thus starfish B II, caught and measured as $4.4 \mathrm{~cm}$. $R$ on Io August, had reached $9.2 \mathrm{~cm}$. $R$ by 30 November. This is an increment of $4.8 \mathrm{~cm}$. in $3 \frac{3}{4}$ months, or 
an average of $\mathrm{I} \cdot 2 \mathrm{~cm}$. per month. This was a fast summer rate and growth decreased from November onwards. The curves show that growth in this starfish and in other similar ones was not steady, but that it appears to have proceeded in a number of steps. This may, of course, have been due to slight errors in measurement.

\section{Table V. Growth Measurements for Well-Fed Individuals OF ASTERIAS RUBENS IN CM.}

\begin{tabular}{|c|c|c|c|c|c|c|c|c|c|c|c|c|c|c|c|c|}
\hline 17 & 9 & 一 & - & 一 & - & 一 & - & 一 & - & - & - & - & - & - & 一 & 一 \\
\hline & & & & & & & & - & & & 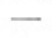 & 一 & - & - & & \\
\hline 6. ii. 47 & $6 \cdot 2$ & $3 \cdot 6$ & $4 \cdot 4$ & 一 & - & - & - & - & - & - & - & - & - & & - & - \\
\hline 2. iii. 47 & $6 \cdot 4$ & $3 \cdot 7$ & $4 \cdot 7$ & 3.0 & - & - & - & - & - & - & - & - & - & - & - & - \\
\hline & & 43 & 5 & $4 \cdot I$ & - & - & - & - & - & - & - & - & - & - & - & \\
\hline 3. iv & $7 \cdot 6$ & $4 \cdot 3$ & 5.5 & & - & 一 & - & - & - & 一 & - & 一 & - & - & - & - \\
\hline $7 . \mathrm{iv}$ & & 4.5 & 5.9 & - & 2 & & - & - & - & - & - & 一 & 一 & - & 一 & \\
\hline & - & $4 \cdot 8$ & $6 \cdot 1$ & - & $7 \cdot 4$ & - & - & - & - & - & - & - & - & 一 & - & 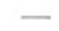 \\
\hline $25 . \mathrm{v}$ & & & $7 \cdot 1$ & - & 0 & $6 \cdot 0$ & - & - & - & - & - & - & - & - & - & \\
\hline & & & $7 \cdot 4$ & - & - 0 & $6 \cdot 4$ & $4 \cdot 8$ & - & - & - & - & - & - & - & - & \\
\hline 29. & & & $8 \cdot 3$ & - & $9 \cdot 4$ & $7 \cdot 3$ & 577 & - & - & - & - & - & - & - & - & \\
\hline 6. v & & & $8 \cdot 6$ & - & & & $6 \cdot 1$ & $I \cdot 3$ & - & - & - & - & - & - & - & \\
\hline 20. v & & 一 & $8 \cdot 8$ & - & - & 8.3 & $6 \cdot 7$ & I. 8 & $I \cdot O$ & - & - & - & - & - & - & - \\
\hline 7 & - & - & 9 & - & - & 9.0 & $7 \cdot 6$ & $2 \cdot 3$ & $\mathrm{I} \cdot 4$ & $8 \cdot 6$ & $4 \cdot 4$ & $4 \cdot 2$ & - & - & - & - \\
\hline I7. viii. 47 & 一 & - & 9. & - & 一 & $9 \cdot 6$ & $8 \cdot 3$ & $2 \cdot 8$ & $\mathrm{I} \cdot \mathrm{C}$ & $8 \cdot 7$ & 4.5 & 2 & $7 \cdot 8$ & $5 \cdot 8$ & - & \\
\hline $4 \cdot y$ & & & 9.8 & - & & & & 0 & $2 \cdot$ & & 49 & $4 \cdot 6$ & & 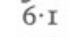 & - & 一 \\
\hline $7 . \mathrm{i}$ & - & - & 一 & - & - & 10.5 & - & $3 \cdot I$ & $2 \cdot 2$ & $10 \cdot 2$ & 6 & $5 \cdot \mathrm{I}$ & $8 \cdot 6$ & 7 & - & 一 \\
\hline I. & - & - & - & - & - & II $\cdot 2$ & - & 3.9 & $2 \cdot 7$ & II $\cdot 0$ & $6 \cdot 6$ & $5 \cdot 3$ & $9 \cdot 2$ & t & 一 & - \\
\hline & & & & - & & & 一 & & 2.8 & II & & & $9 \cdot 4$ & $8 \cdot 8$ & & \\
\hline 26 & - & 一 & - & - & - & II $\cdot 9$ & - & - & $3 \cdot 2$ & I 2.4 & & - & - & 10.3 & $6 \cdot 3$ & - \\
\hline & - & - & - & - & - & II $\cdot 9$ & - & - & $3 \cdot 4$ & 一 & 8.8 & - & - & 10. 4 & 5.2 & 一 \\
\hline & & & & - & & . & - & & 4 & - & 9 & - & - & I0.7 & 5.9 & \\
\hline 7. & & - & - & - & - & - & - & 一 & 4 & - & $9 \cdot 3$ & - & - & - & $7 \cdot 0$ & \\
\hline I4. & - & & - & - & - & 一 & - & - & 5.0 & - & $9 \cdot 3$ & - & - & & $7 \cdot 0$ & \\
\hline & & & & 一 & & 一 & 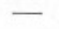 & - & & - & & - & - & - & & • \\
\hline r. ii.: 48 & - & - & - & 一 & - & 一 & - & - & - & - & - & - & - & - & 一 & 10.7 \\
\hline & & & - & 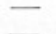 & & 二 & & 二 & 二 & & - & & - & & & \\
\hline & & & - & - & - & & & - & & - & & - & - & - & - & $\mathrm{I} \cdot 3$ \\
\hline
\end{tabular}

A few growth curves were obtained for starfishes almost certainly belonging to the 1947 brood. Starfish B 9 was caught on 20 July 1947 on a clump of Mytilus edulis and it then measured I cm. $R$. By 7 December 1947 it measured $4.8 \mathrm{~cm}$., an increment of $3.8 \mathrm{~cm}$. in $3^{\frac{2}{3}}$ months, or about $\mathrm{I} \mathrm{cm}$. (average) per month. Some idea of the size likely to have been reached by starfish B 9 by April 1948 may be obtained by referring to the growth curve of another well-fed starfish B I which measured $5.9 \mathrm{~cm}$. $R$ on 26 Janúary 1947. By 13 April 1947 this starfish had grown to $7.6 \mathrm{~cm}$. $R$, an increment of $1.7 \mathrm{~cm}$. in $2 \frac{1}{2}$ months, or an average (winter) monthly increment of $0.7 \mathrm{~cm}$.

From the present observations on growth rate it is clear that small and very small starfishes (up to at least $6 \mathrm{~cm}$. $R$ ) can grow at a monthly rate of rather more than $\mathrm{I} \mathrm{cm}$. in summer and autumn and of rather less than $0.5 \mathrm{~cm}$. in winter. These rates are only attained when the food supply is abundant. 


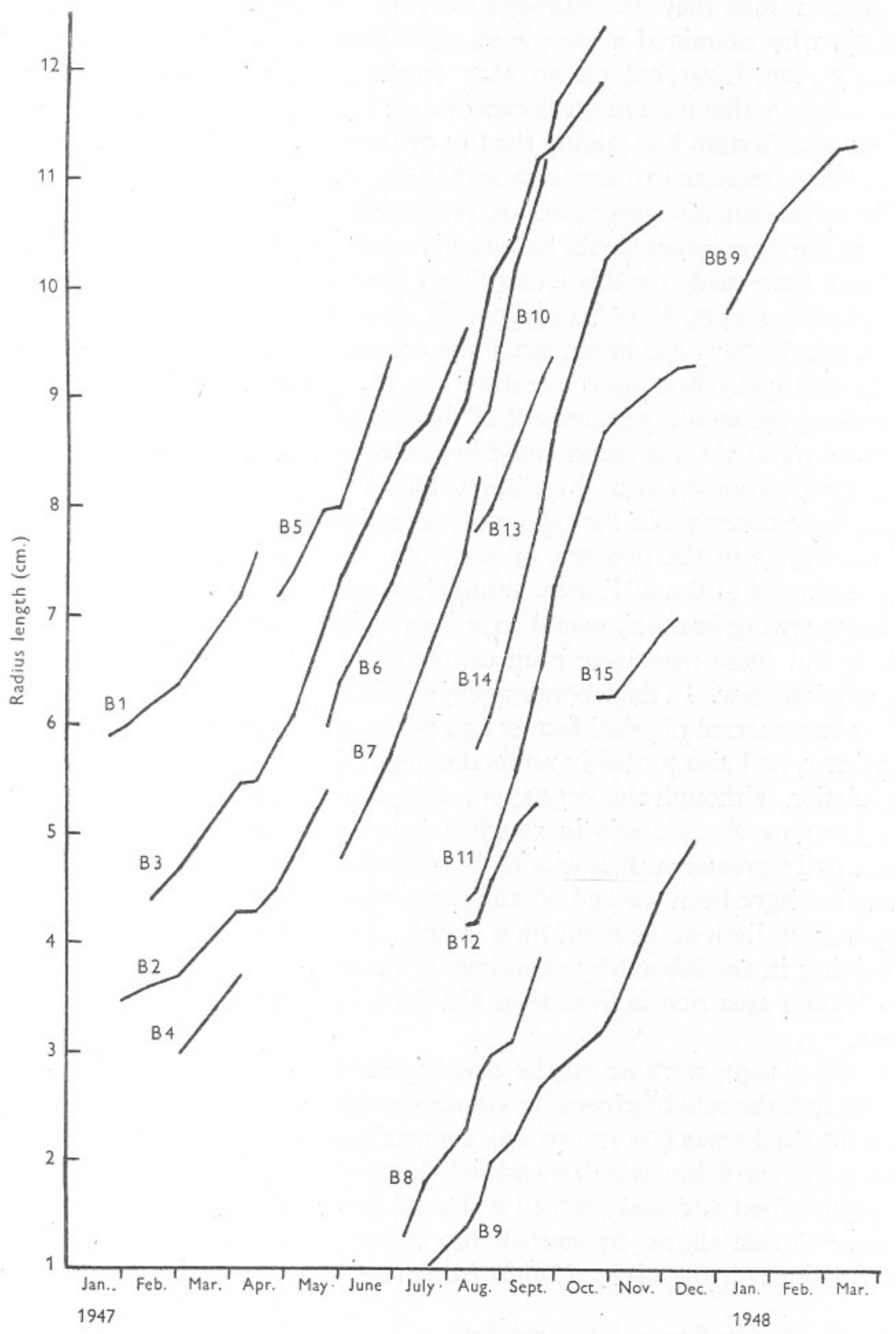

Fig. 2. Growth curves of well-fed A. rubens plotted from Table V. 
These results may be compared with the observations of Orton \& Fraser (I930), who examined a sample of I800 young Asterias rubens taken from a buoy near Liverpool on 30 May 1930. Their method of measurement differed from that used in the present work; they expressed size in terms of the length of a straight line joining the tips of alternate arms. Their values for size have been converted to conform with those used in this study. In addition, their measurements were taken on preserved specimens, and they suggested that in life their values would have been on an average $5 \mathrm{~mm}$. larger; allowance has also been made for this factor. They found that the modal value of their sample was $2.2 \mathrm{~cm}$. $R$ with a range from 0.6 to $5.2 \mathrm{~cm}$., and, knowing the date on which the buoy had been placed in position, they reckoned that this amount of growth had taken place in rather less than a year. On this information, therefore, the monthly increment of the starfishes round the mode was about $0.25 \mathrm{~cm}$., and the maximum monthly increment a little more than $0.5 \mathrm{~cm}$. Their population appears, therefore, to have been growing considerably slower than those observed in the laboratory experiments. However, the total sum of conditions in the two sets of starfishes is not strictly comparable. The population of Orton \& Fraser, although surrounded by a plentiful supply of young growing mussels, would have been subject to the action of waves and wind, and there may have been competition for suitably sized food as the population grew. In the laboratory experiments, on the other hand, there were no severe external physical factors except the seasonal decrease in temperature in winter, and also probably no food competition. Furthermore, in the buoy population, although the very small sizes would have no difficulty in hiding away among the mussels in rough weather, the larger starfishes will have presented a greater surface area to the action of the waves. Some of them may therefore have been washed off the buoy, thus reducing the modal value and upper range limit of the population sample. It is considered that the conditions obtaining in the laboratory experiments more closely resembled those on a sea bottom area rich in food than did those in the population on the floating buoy.

Mead (1899), working on the closely related species $A$. forbesi Desor, also found that the rate of growth in young specimens fed on plentiful supplies of lamellibranchs was fast and strictly comparable with the present observations. One of his starfishes, which measured about I. $8 \mathrm{~cm}$. on I 8 August, was fed on abundant food and had reached a size of $3.5 \mathrm{~cm}$. $R$ by 26 September, a rate similar to that shown by starfish B 9 of the present observations. Further observations on growth in A. forbesi are given by Galtsoff \& Loosanoff (I939).

\section{Growth Rate in Poorly-fed Starfishes}

As control to these experiments a number of starfishes were kept in a separate tank with a minimum of food (a few small barnacles only). They were measured periodically and it was found that no measurable growth occurred, 
and in a few the length of the radius actually decreased, although the amount of reduction was within the limits of accuracy of the method of measurement.

As a further control experiment, starfishes of known size were placed in three boxes on a raft in Plymouth Sound on I3 December 1946.

Six $A$. rubens were placed in box $\mathrm{R}$ together with six Tellina crassa, three Paphia rhomboides and one Venus casina. Each starfish measured $R=6 \mathrm{~cm} . \pm 0 \cdot \mathrm{I}$. No further food was added and the box was left undisturbed until 2I May I948 when it contained: three Asterias rubens $(R=6 \cdot 4,6 \cdot 2$, and $6 \cdot 2 \mathrm{~cm}$.), eight Ciona intestinalis, four Ascidiella aspersa, two Polycirrus caliendrum, and numerous fassa falcata, as well as the empty shells of the original molluscs. Besides the latter, it is probable that the three surviving starfishes had eaten the remains of the three which had died, as well as possible spatfalls of barnacles.

Boxes L and C each started with six Asterias rubens of the same size as in box R, but without any food. When opened on 2I May I 948 they contained:

Box L

Three $A$. rubens $(R=5 \cdot 8,5 \cdot 7,5 \cdot 0 \mathrm{~cm}$.)

Two colonies Leucosolenia sp.

Numerous fassa falcata

Box C

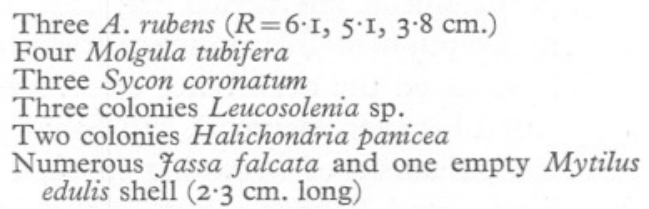

Three $A$. rubens $(R=6 \cdot \mathrm{I}, 5 \cdot \mathrm{I}, 3 \cdot 8 \mathrm{~cm}$.)

Four Molgula tubifera

Three colonies Leucosolenia sp.

Two colonies Halichondria panicea edulis shell $(2 \cdot 3 \mathrm{~cm}$. long)

In these boxes the surviving starfishes would again have had the remains of the dead starfishes to feed on, as well as possible spatfalls. In box $\mathrm{C}$ the Mytilus had also almost certainly been eaten by one of the starfishes.

In all three boxes the amount of food available was infinitesimal in comparison with the long period of the experiment ( $17 \frac{1}{4}$ months). The starfishes were, therefore, to all intents without food during the greater part of this period and, as the measurements show, there was no significant growth. All the starfishes which survived were emaciated and darker in colour than at the outset of the experiment. In the three individuals which showed a significant decrease in size the arrangement of the spines on the aboral side and of the ambulacral plates suggested a marked contraction of the muscles between the various skeletal plates. This apparent contraction may have been due to actual resorption of muscle tissue, and further observations are being made to check this explanation.

Lack of food therefore stops growth, as would be expected, but this cessation of growth is not necessarily followed by the death of the animal, since it has been shown that starfishes will live for at least 17 months with practically no food. This means that it is not possible to tell the age of a starfish from its size, and a starfish I year old may, in fact, measure anything between about $I$ and $9 \mathrm{~cm}$. in radius. 


\section{Criteria of Breeding}

\section{REPRODUCTION}

Three main phases may be recognized in the reproduction of a marine invertebrate:

(a) Maturing of the gametes in the parent gonad.

(b) Spawning of the gametes, usually directly into the sea, and fertilization.

(c) Development of the fertilized egg into the adult, usually with an intermediate free-swimming larval stage.

With Asterias rubens reliable observations on the reproductive period have been largely based on records of larvae in different localities. Examination of these records shows that there is considerable variation from year to year in the period at which larvae were taken, even in the same locality. There is, however, no certain way of knowing from which local population the larvae have been derived, as they may be carried away from the area in which they were spawned by the action of currents. Collections of larvae have often been taken sporadically and not regularly throughout the year, so that the absence of a record during any period may only mean that no collections were made. As an exception to this criticism mention should be made of the valuable observations on the occurrence of $A$. rubens and other echinoderm larvae in the Sound between Denmark and Sweden recorded by Thorson (I946).

The mechanism of spawning (phase $b$ ) has been studied in echinoids by Fox (1924) and Palmer (1937). In A. rubens Gemmill (1914) found that spawning may be induced by the presence of sperms and ova, but he did not separate ova from sperm when they were used as stimuli to spawning.

The present work is primarily concerned with phase $a$, the process of gonad ripening within wild populations, as distinct from the cytology of gamete maturation-which has been described for $A$. rubens by Gemmill (I9I4). Data on this process in a number of separated populations may give information on the factors controlling the differences in productivity of the bottom fauna of different areas. Regular examinations were made of the state of the gonads in the parent starfishes.

The relation between body size in $A$. rubens and the size of the gonads varies greatly according to the time of the year. After the breeding season the gonads are thin, short and shrunken caeca, almost never exceeding $2-3 \mathrm{~cm}$. in length, even in the largest starfish. During the period of maturity, on the other hand, the gonads are very large and may extend from their origin near the interradial angle almost to the tip of the arm.

Although this increase is very largely one of volume, the coelomic cavity of the arms in which the maturing gonads are at liberty to grow is essentially elongated, and it has been found most practicable to denote gonad size by length measurements. This method of gonad measurement also allows a direct comparison to be made between gonad size and the size of the parent animal expressed in terms of radius length. 


\section{Stages of Ovarian Maturity}

The gonads of all the starfishes taken in the hauls were examined living, and records were kept of the state of sexual maturity. To allow comparison of the gonad states between one catch and the next an arbitrary scheme of stages of ovarian maturity was used. This was not attempted in the male, where any separation of stages beyond 'unripe', 'ripe' and 'spawned' was found to be unreliable. For the ovaries six stages of maturity were defined, primarily in terms of the sizes of the oocytes and eggs, but account was also taken of the outer appearance and length of each ovary. Examination of the colour and texture only does not provide a reliable criterion of the stage of sexual maturity reached.

The six stages of ovarian maturity were defined as follows:

I. Very immature. Ovary transparent and thin, with a length usually between 0.1 and $0.5 \mathrm{~cm}$. Few early transparent oocytes, with no trace of yolk, up to $40 \mu$ in diameter. Most ovaries in this stage were probably virgin.

2. Immature. Ovary opaque; length usually between 0.5 and $1.5 \mathrm{~cm}$. Oocytes still transparent, without yolk, but more numerous and up to $80 \mu$ in diameter. This stage included many virgin starfishes, but also probably a few which had bred before.

3. Ripening. Ovary always opaque, white to yellowish, and more than $\mathrm{I} \mathrm{cm}$. in length. Distinguished at once from stage 2 by the very numerous oocytes, all yolky, and varying in diameter between $200 \mu$ and the diameter of the ripe eggs.

4. Ripe. Ovary almost translucent and greatly enlarged with swollen caeca, and nearly always longer than $1.5 \mathrm{~cm}$. The maximum length of the ripe ovary varies considerably, but is commonly between one-tenth and two-fifths of the radius length, sometimes up to seven-eighths of this length. Containing $90 \%$ or over of ripe eggs.

5. Spawned. Ovary opaque and yellow with shrunken caeca. Usually between $\mathrm{I}$ and $4 \mathrm{~cm}$. in length, according to the size of the animal. A few oocytes appear in a smear, but the distinguishing character is the residue of a few ripe but unspawned eggs which are in process of breaking up, their yolky material being ingested by amoebocytes.

6. Spawned and Re-ripening. Ovary similar in shape and size to that in stage 5, but no unspawned eggs remain, and a fresh generation of yolky oocytes has appeared. This stage occurs in late summer and can be recognized with some certainty up to September. After this it is not distinguishable from stage 3 and so from I October all records of this type of ovary with yolky oocytes are recorded as stage 3 .

The sequence of stages in the life of an individual starfish appears, therefore, to be
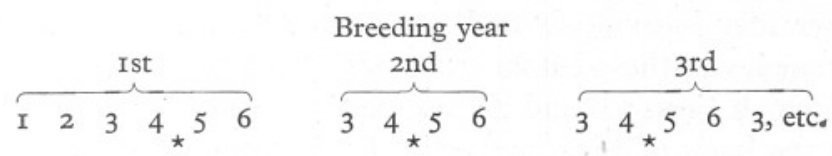

JOURN. MAR. BIOL. ASSOC. vol. XXVIII, I949 
In each year spawning is indicated by an asterisk. Starfishes which have once bred never appear to pass through stage I again, although it is possible that a few may return to stage 2 . The available evidence shows, however, that after spawning a population never shows any significant increase in the number of individuals in ovarian stage 2 . In a few individual starfish the ovaries may show signs of complete atrophy as opposed to the normal seasonal regression.

\section{Analysis of Reproductive Cycles}

Rame-Eddystone Grounds. The percentages in each stage of ovarian maturity in 1947 are plotted graphically against time in Fig. 3A. Although each point in this graph is based on a relatively small number of females (owing to the small catches in this area), it is quite evident that the number of females which actually reached sexual maturity (stage 4) during 1947 was surprisingly small. Ripe ovaries were, in fact, only found in the two April catches of this year, and then only in 17 and $19 \%$ of the females. This small proportion of ripe females is reflected later in the season in the small percentages of stage 5 recorded. Fig. $3 \mathrm{~A}$ also shows the large and steady percentages of stages $\mathrm{I}$ and 2 during I947. The peak values for stages I and 2 in June and July I947 are probably due to the arrival in the catches of young starfishes which the trawl had previously failed to capture but which had by then reached a catchable size. It is unlikely that these young starfishes had bred before, but they would probably have done so in the following year (1948), that is when they were 2 years old. As their ovaries start to mature in preparation for this breeding the values for stages $I$ and 2 should fall off and stage 3 should increase. This is beginning to happen in September and October 1947 .

During 1947, therefore, less than $20 \%$ of the total female population of starfishes (over $R=3 \mathrm{~cm}$.) on these grounds produced ripe eggs.

In 1948 comparable samples from the same grounds showed a similar breeding cycle, but with important modifications (Fig. 4A). The most noticeable difference was the greater length of time during which ripe eggs were recorded in 1948, namely February till the beginning of June, with peak egg production in April and May. In 1948, however, the percentage of definitely non-breeding starfishes (stages I and 2) was still high, being approximately $40 \%$ compared with $50-70 \%$ in 1947 .

The Outer Grounds. On these grounds the observations on state of maturity showed an entirely different picture. The percentages in each stage of ovarian maturity in 1947 and 1948 are plotted graphically against time in Figs. 3 B and $4 \mathrm{~B}$. Nearly all the catches from this area were large, the majority totalling over fifty individuals and some over I00. Furthermore, the proportion of females in these catches was nearly always above $50 \%$ and so the samples on which Figs. $3 \mathrm{~B}$ and ${ }_{4} \mathrm{~B}$ are based are relatively larger than those which form the basis of Figs. $3 \mathrm{~A}$ and $4 \mathrm{~A}$. Fig. $3 \mathrm{~B}$ shows that ripe females 
were already present (II \%) in the population on 7 March, the date of the first catch from this area. The percentage of ripe females increased from then onwards to a peak in the second half of April. On 23 May 1947 there were no
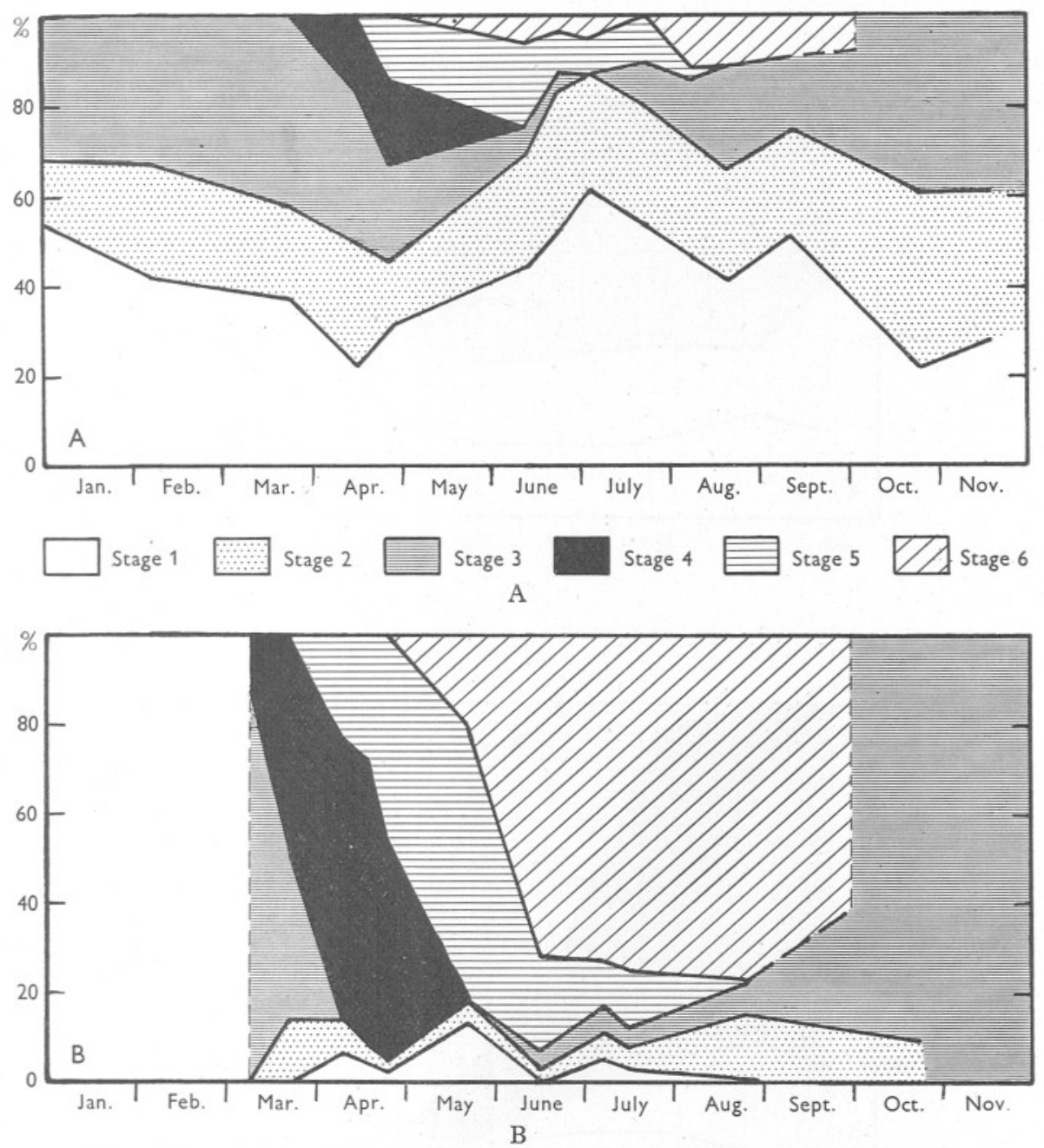

Fig. 3. Ovarian maturity. Percentages in each stage during 1947. A, RameEddystone Grounds; B, Outer Grounds.

ripe females in the population sample. Stage 5 females were dominant in the population in May and the first half of June. After this 'recently spawned' ovaries were again scarce, as they gave place to those in stage 6 .

In this area the proportions of stages I and 2 combined are remarkably constant and never exceeded I $5 \%$ of the total population of females. 
During 1948 the reproductive cycle (Fig. 4 b) was essentially similar to that of 1947. Data are, however, available for the early part of 1948 , and they show that ripe eggs were produced from February till the end of May with a peak in March and April.
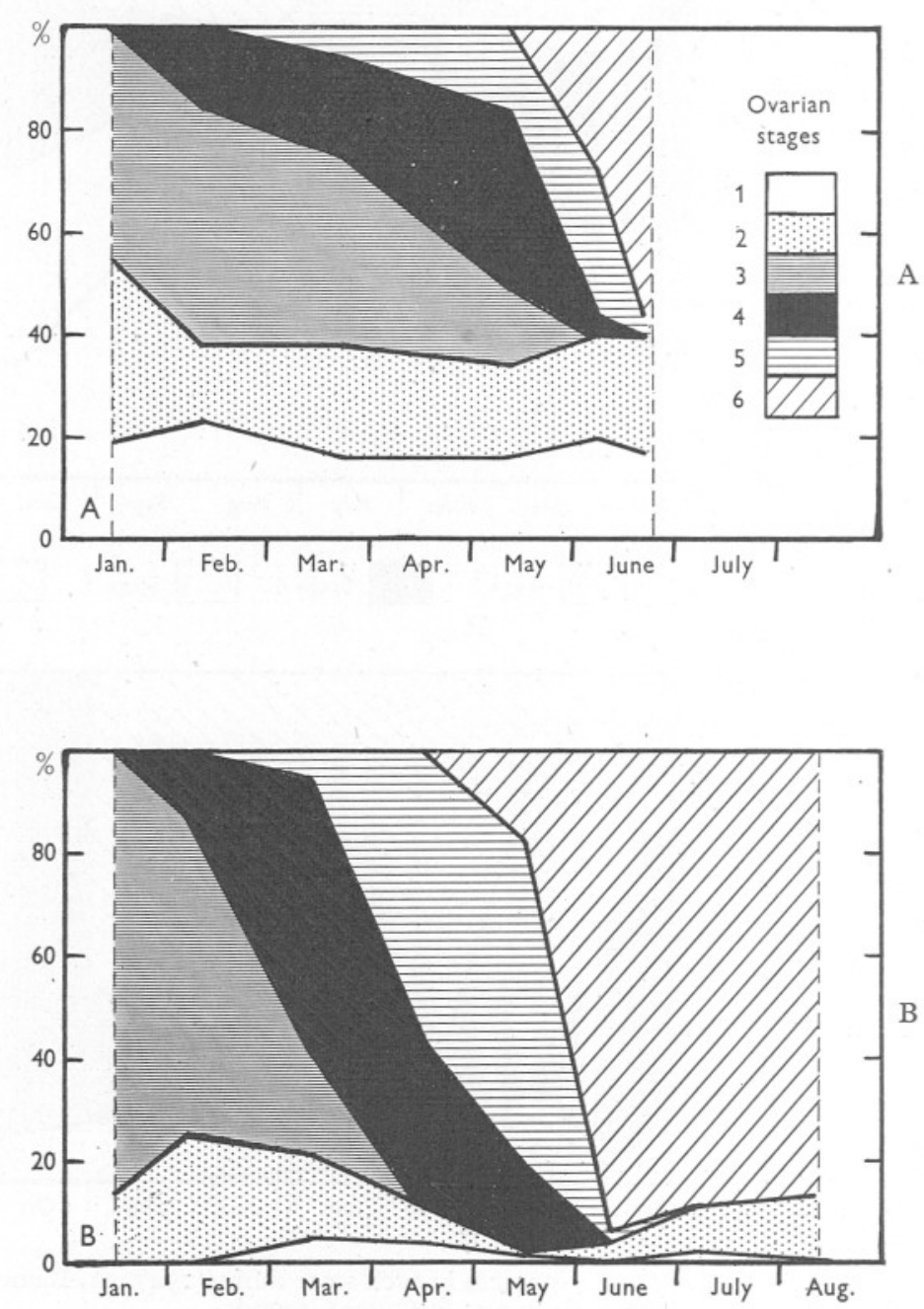

Fig. 4. Ovarian maturity. Percentages in each stage during 1948. A, Rame-Eddystone Grounds; B, Outer Grounds.

On the Outer Grounds the data for both 1947 and 1948 show that the proportions of stages I and 2 combined are very constant and only once (early 1948) exceeded $20 \%$ of the total population of ovaries. 
The Population near $E \mathrm{I}$. By the time samples were obtained in the area the majority of individuals had already spawned; this is clear from Table VI, which suggests that the peak of the spawning period in 1947 had taken place in May, and so probably a little later than in the Outer Grounds population.

The Cawsand Bay Population. Only one haul was obtained from this area (on 23 May 1947), and as already mentioned the starfishes were all very small and almost certainly belonged to the 1946 brood. In spite of their small size eight of the ten females had already spawned (stage 5), with ripe eggs still present in some tubules. Also two of the eight males were still ripe with motile sperms, and two others showed signs of having spawned recently.

The Plymouth Sound Population. The characteristics of the reproductive cycle in this population were as homogeneous as the size composition. On Io February 1948 fourteen females were taken, of which one had ovaries in stage 2 and thirteen in stage 3. On I6 April forty-eight females were caught and all were ripe (stage 4 ).

The Rame Mud Population. In the single sample of ninety-five starfishes from this area only seventeen could be sexed, and of these only five were females, all with ripe gonads. Breeding in this area was evidently very intermittent.

\section{Relation between Ovarian Maturity and Body Size}

The criterion of ovarian maturity has been used as an index of the potential breeding efficiency of a number of populations and certain conclusions may now be drawn. Of the two populations most extensively studied that on the Outer Grounds showed a significantly higher percentage of ripe ovaries than the Rame-Eddystone Grounds population. At first sight it might appear that this difference in percentage of females matured between the Rame-Eddystone and the Outer Grounds populations was related to body size, namely that the larger individuals matured and the smaller ones did not. This might explain the differences in maturing between the large-sized and the medium-sized populations, but it would not account for the high percentage of maturity in the small-sized Cawsand Bay population. Nor would it account for the difference in maturity between the Rame-Eddystone population and the somewhat smaller-sized Plymouth Sound population. On I6 April 1948 the Plymouth Sound female starfishes had a mean radius length of $9.5 \mathrm{~cm}$. and $100 \%$ of the females had ripe ovaries. In the Rame-Eddystone population at the peak of the breeding season (as determined by the percentage ovarian maturity, II May 1948) only $34 \%$ of the females were ripe, and yet the starfishes in this sample were somewhat larger (mean $R=10.5 \mathrm{~cm}$.) than those in Plymouth Sound.

Furthermore, analysis of the sizes of the mature females in the RameEddystone and Outer Grounds populations provides interesting data. The size distributions of the female starfishes in stages 4 and 5 from the Rame- 
Eddystone sample for 28 April 1947 and from the Outer Grounds sample for 25 April 1947 are shown in Table VI. This shows that the size classes $R=6 \mathrm{~cm}$. and $R=9-\mathrm{I} 3 \mathrm{~cm}$. were represented in both samples.

\section{Table VI. Number of Females in Stages 4 OR 5 in Equal-sized Starfishes From Two Populations}

\begin{tabular}{|c|c|c|c|c|c|c|c|c|c|c|c|c|c|c|c|}
\hline \multirow[b]{2}{*}{ Grounds and date } & \multirow[b]{3}{*}{ Total 우우 } & \multicolumn{14}{|c|}{ Size class in $\mathrm{cm}$. } \\
\hline & & 5 & 6 & 7 & 8 & 9 & Io & II & I2 & 13 & $\mathrm{I} 4$ & 15 & I6 & I7 & I8 \\
\hline Rame-Eddystone & & I & 4 & 6 & Io & 6 & 4 & 5 & 2 & 4 & o & ० & $\circ$ & $\circ$ & ○ \\
\hline & $\begin{array}{l}\text { 우우 in stages } \\
4 \text { or } 5\end{array}$ & I & I & $\circ$ & I & 3 & 2 & 2 & 2 & 2 & ○ & $\circ$ & $\circ$ & $\circ$ & ○ \\
\hline Outer Grounds & Total 우우 & o & I & $\circ$ & $\circ$ & I & 2 & 5 & 8 & I6 & I3 & I6 & 25 & 12 & 6 \\
\hline (25. iv & $\begin{array}{l}\text { 우우 in stages } \\
4 \text { or } 5\end{array}$ & 0 & ० & $\circ$ & ० & I & I & 5 & 7 & I5 & II & I4 & 23 & II & 6 \\
\hline
\end{tabular}

Analysis of the numbers of stages 4 and 5 in these common size classes shows that: Rame-Eddystone Grounds had twelve in breeding condition out of twenty-five ( $48 \%$ ); Outer Grounds had twenty-nine in breeding condition out of thirty-three ( $88 \%$ ).

Similarly, comparison of the common size classes in the other pair of contemporaneous breeding-season samples shows that: Rame-Eddystone Grounds (I6 April I947) had two in breeding condition out of seven; and Outer Grounds (I8 April 1947) had ten in breeding condition out of eleven.

It appears, therefore, from a comparison of the Outer Grounds and the Rame-Eddystone Grounds populations, that there was a marked difference in the incidence of ripe and spawned ovaries among equal-sized starfishes on these grounds, over $85 \%$ of the Outer Grounds female starfishes having reached breeding condition, while on the Rame-Eddystone Grounds under $50 \%$ had reached this stage.

The length of the season during which ripe eggs were present was no longer in the Rame Eddystone Grounds than in the Outer Grounds, so that there is no lengthening of the breeding season to account for the low percentage of ripe females on the dates on which samples were taken. Indeed, during I947, the ripe-egg season in the Rame-Eddystone Grounds was considerably shorter than in the Outer Grounds.

\section{Ovary Lengths and Relative Egg Production}

The previous analysis gives an index of the number of individuals reaching stages 4-5, but gives no indication of any difference in the scale of gamete production between equal-staged starfishes in different populations. A further analysis of the lengths of the ripe ovaries (stage 4) in equal-sized starfishes from contemporaneous samples is shown graphically in Fig. 5. This shows that in equal-sized starfishes in April 1947 ripe ovaries were longer in the Outer Grounds than they were in the Rame-Eddystone Grounds and, 
similarly, they were significantly longer in April 1948 in the Plymouth Sound population than in the early May 1948 sample from the Rame-Eddystone

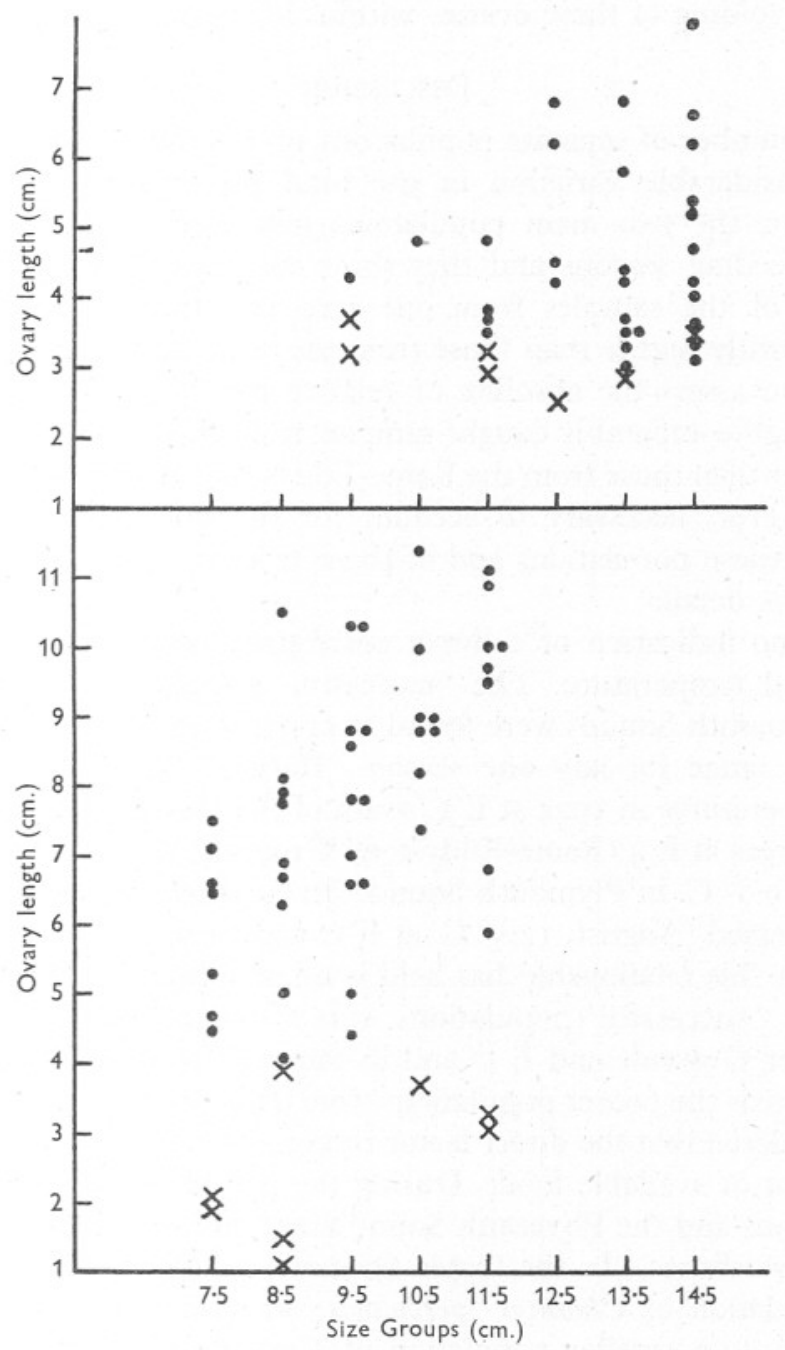

Fig. 5. Lengths of ovaries in stage- 4 starfishes in different populations. Above: $\times$, RameEddystone Grounds on 16 and 28 April I947; 9, Outer Grounds on 9, I8 and 25 April I947. Below: $\times$, Rame-Eddystone Grounds on II May I948; 9, Plymouth Sound on I6 April r 948 .

Grounds. The production of eggs in the Outer Grounds and Plymouth Sound populations must therefore have been considerably greater than in the RameEddystone Grounds population. 
It is interesting to note that in April I948 the ovaries from the Plymouth Sound sample were sometimes longer, when dissected out, than the starfish arms in which they had been growing. This was due to a certain amount of longitudinal folding of these ovaries within the coelomic cavity of the arms.

\section{DisCUSSION}

Study of a number of separate populations of Asterias rubens has shown that there is considerable variation in the total productivity on the different grounds. For the two main populations investigated, data were collected over two breeding seasons and they show conclusively that the size means and ranges of the samples from one area and their percentage matured were significantly higher than those from the other area. No attempt has yet been made to assess the absolute or relative numbers of starfishes in these areas, although comparably caught samples from the Outer Grounds were in general larger than those from the Rame-Eddystone Grounds. Some explanation is, however, necessary to account for the differences in growth and maturing of these populations and of those from the other areas which were studied in less detail.

There is no indication of a direct correlation between good growth and maturing and temperature. The 'successful' populations (Outer Grounds, E I, and Plymouth Sound) were found at opposite extremes of the very small temperature range for any one season. Harvey (1928) found that winter bottom temperatures in 1924 at E I (south of the Outer Grounds) were about $10^{\circ} \mathrm{C}$., whereas at L 4 (Rame-Eddystone Grounds) they were approximately $9.8^{\circ} \mathrm{C}$., and 9. $0^{\circ} \mathrm{C}$. in Plymouth Sound. In summer, however, this relationship was reversed (August, $\mathrm{I} 2.5^{\circ} \mathrm{C}$. at $\mathrm{E} \mathrm{I}$, and $13.5^{\circ} \mathrm{C}$. at L 4). With minor modifications this relationship has held good in subsequent years. Similarly, with salinity, 'successful' populations were found in both the least polluted waters (Outer Grounds and E I) and in the most polluted waters (Plymouth Sound), whereas the poorer populations were living in the intermediate waters.

It is considered that the direct factor responsible for the differences noticed is the amount of available food. During the period of the investigations the Outer Grounds and the Plymouth Sound area were very rich in food animals suitable for starfishes. In the Outer Grounds the flat sandy bottom carried a large population of Chlamys opercularis, which formed the chief starfish food, as well as a smaller population of Cyprina islandica, which is eaten by large specimens of Asterias sp. (Hunt, 1925). In the Asia Grounds where the rich Plymouth Sound starfish population was found, the trawl brought up many medium and large Mytilus edulis. On the other hand, in the Rame-Eddystone Grounds it is difficult to name any one main food source for the starfishes living there. Trawl and dredge hauls brought up a few Chlamys opercularis, and a few tubicolous worms, as well as large clusters of hydroids and bryozoans. In these clusters there were small crabs, lamelli- 
branchs and other starfishes, but little that could serve as a main food supply for medium and large starfishes. The same may be said of the Rame Mud area, where the epifauna is even poorer, although the infauna, which is largely inaccessible to Asterias, is relatively abundant.

The abundance of the supply of Mytilus in Plymouth Sound in 1948 was probably the result of an exceptionally good spatfall correlated with the presence of detritus brought down by the rivers Plym, Tamar and Tavy and by the Plymouth City effluents, all of which flow into the Sound; in addition plankton would be brought in from the open sea. A heavy spatfall of Mytilus coinciding in time and space with a rich settlement of Asterias rubens will provide ideal conditions for the growth of a large starfish population, such as that investigated in Plymouth Sound in 1948. On the other hand, large numbers of young starfishes settling on a bed of adult mussels would not thrive, since their size would be out of phase with that of the food animal. There must, therefore, be a rather limited optimum mean size and total concentration of the food animal before a large homogeneous population of starfishes can be produced. These conditions have been fulfilled on Asia Grounds, but not on the RameEddystone Grounds or on the Rame Mud.

For the Outer Grounds population a different food animal is involved, and whereas a heavy spatfall of Mytilus in Plymouth Sound is apparently rare, it is probable that good spatfalls of Chlamys are quite usual in the waters of the English Channel. The ultimate factors responsible for the distribution of Chlamys are not known, although it is possible that, as they are active swimmers, they may move away from areas poor in food and congregate in more favourable waters. At the same time they are known actively to avoid concentrations of Asterias rubens, which will in their turn follow the Chlamys. The distribution of Chlamys on the sea bottom is, therefore, probably a resultant of both these biological factors. Whereas the Plymouth Sound population, feeding on an abundant fixed food animal, was itself strictly localized in distribution, the Outer Grounds population feeding on a mobile food animal was probably moving to and fro on the sea bottom in pursuit of Chlamys. Furthermore, as the Chlamys move about, neighbouring groups of Asterias will be attracted to the fringes of the Outer Grounds. If this type of dilution of the population occurs, it would account for the wide size ranges of some of the Outer Grounds samples and the dispersion of their means (Fig. I). There is no evidence for regarding these movements of Asterias and Chlamys as large-scale migrations involving long distances.

There is no sharp limiting boundary between the Rame-Eddystone and the Outer Grounds populations, although, in practice, the 30 -fathom line has been regarded as a convenient line of demarcation, and it is probable that starfishes from the Rame-Eddystone Grounds play a part in the dilution of the Outer Grounds population. On the basis of the growth-rate observations it is likely that many Outer Grounds starfishes had metamorphosed there and had reached 
medium size $(R=c a .6-10 \mathrm{~cm}$.) and breeding condition in one year. On the other hand, other starfishes of similar sizes caught on the same grounds were probably immigrants, aged 2 or even 3 years, from the Rame-Eddystone Grounds and other neighbouring areas.

There is, unfortunately, no method of determining age in Asterias. However, investigation of different wild populations coupled with growth-rate observations have shown that the productivity of a starfish population, as measured by the percentage of matured gonads and by the sizes of these gonads, is not primarily correlated with age. Poorly fed populations will survive and show minimum growth and little or no gonad maturing, whereas well fed populations will grow fast and reach breeding condition within one year from metamorphosis.

\section{SUMMARY}

Considerable differences were found in the size compositions of populations of Asterias rubens off Plymouth. These differences were not correlated with age.

Laboratory observations on rate of growth showed that well fed starfishes grow fast during summer and autumn and somewhat slower in winter. Poorly fed starfishes did not increase in size, but were able to survive for long periods with a minimum of food.

In favourable conditions $A$. rubens may grow to a radius size of $8-9 \mathrm{~cm}$. in one year and may also reach breeding condition during this time.

Investigation of breeding cycles by determination of the percentage of females in different stages of ovarian maturity showed further differences between populations. Starfish populations with a high percentage of large and ripe ovaries during the breeding season were not necessarily those with large body-size means.

It is considered that the differences in size composition and production of ripe eggs were primarily correlated with food, and observations are given on the food animals in the areas supporting 'successful' starfish populations.

For the production of a large homogeneous starfish population it is necessary for spat to fall on an area rich in suitable food animals. There is an optimum relationship between size of starfish and size of food animal which must be maintained if the starfish population is to remain large and homogeneous and show maximum productivity during the breeding season.

\section{REFERENCES}

Allen, E. J., I899. On the fauna and bottom-deposits near the thirty-fathom line from the Eddystone Grounds to Start Point. Fourn. Mar. Biol. Assoc., Vol. v, pp. $365-542$.

Fox, H. M., I924. The spawning of echinoids. Proc. Camb. Phil. Soc. (Biol. Sci.), Vol. I, pp. $7 \mathrm{I}-4$.

GaLtSOFF, P. S. \& LoosanOFF, V. L., I939. Natural History and method of controlling the starfish (Asterias forbesi Desor). Bull. U.S. Bur. Fisheries, No. 49, pp. 75-132. 
Gemmill, J. F., I9I4. The development and certain points in the adult structure of the starfish Asterias rubens L. Phil. Trans. Roy. Soc., B, Vol. 205, pp. 213-94.

Harvey, H. W., I928. Biological Chemistry and Physics of Sea Water. Cambridge University Press.

Hunt, O. D., I925. The food of the bottom fauna of the Plymouth fishing grounds. Fourn. Mar. Biol. Assoc., Vol. xiII, pp. 560-98.

MeAd, A. D., I899. Special Report on the Starfish. 29th Ann. Rep. Comm. Inland Fisheries, Rhode Island, pp. 37-76.

Mortensen, Th., 1927. Handbook of the Echinoderms of the British Isles. Oxford University Press.

Orton, J. H. \& Fraser, J. H., I930. Rate of growth of the common starfish, Asterias rubens. Nature, Vol. I26, p. 567.

Palmer, L., I937. The shedding reaction in Arbacia punctulata. Physiol. Zool., Vol. Io, pp. $352-67$.

Thorson, G., I946. Reproduction and larval development of Danish marine bottom invertebrates, with special reference to the planktonic larvae in the Sound (Øresund). Medd. Komm. Danmarks Fisk. Havund., Kobenhavn, Ser. Plankton, Bd. 4, No. I, 523 pp. 